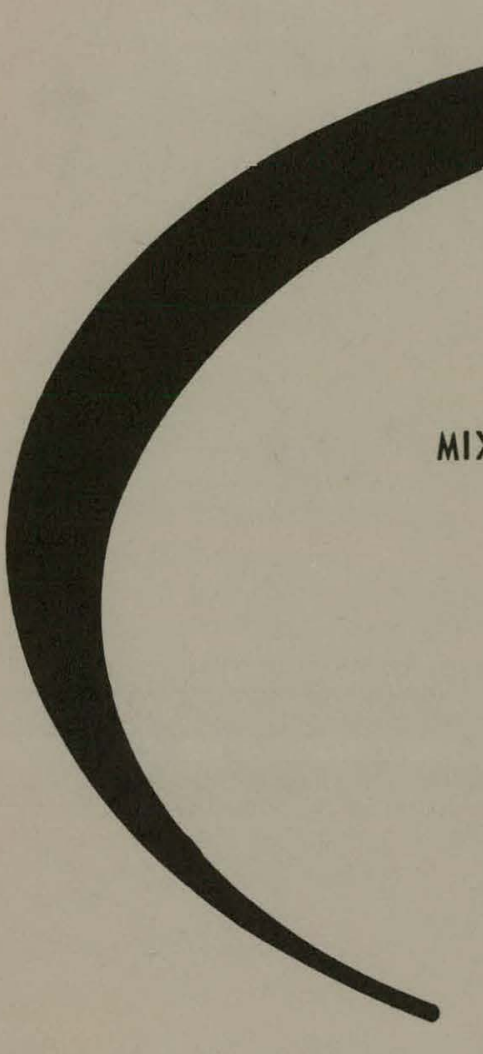

MIXTURES OF PLUTONIUM AND ENRICHED

URANIUM IN SLAB GEOMETRY

C. Lee Schuske

Donald C. Coonfield

THIS DOCUMENT CONFIRMED AS UNCLASSIFIED

DIVISION OF CLASSIFICATION

BY

DATE

9HKahnlamk

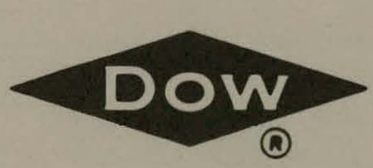

THE DOW CHEMICAL COMPANY

ROCKY FLATS DIVISION

P. O. BOX 888

GOLDEN, COLORADO 80401

U.S. ATOMIC ENERGY COMMISSION

CONTRACT AT(29-1)-1106 


\section{DISCLAIMER}

This report was prepared as an account of work sponsored by an agency of the United States Government. Neither the United States Government nor any agency Thereof, nor any of their employees, makes any warranty, express or implied, or assumes any legal liability or responsibility for the accuracy, completeness, or usefulness of any information, apparatus, product, or process disclosed, or represents that its use would not infringe privately owned rights. Reference herein to any specific commercial product, process, or service by trade name, trademark, manufacturer, or otherwise does not necessarily constitute or imply its endorsement, recommendation, or favoring by the United States Government or any agency thereof. The views and opinions of authors expressed herein do not necessarily state or reflect those of the United States Government or any agency thereof. 


\section{DISCLAIMER}

Portions of this document may be illegible in electronic image products. Images are produced from the best available original document. 


\section{LEGAL NOTICE}

This report was prcpared as an account of work sponsored by the United States Government. Neither the United States nor the United States Atomic Energy Commission, nor any of their employees, nor any of their contractors, subcontractors, or their employees, makes any warranty, expressed or implied, or assumes any legal liability or responsibility for the accuracy, completeness or usefulness of any information, apparatus, product or process disclosed, or represents that its use would not infringe privately owned rights.

Printed in the United States of America

Available from the

National Technical Information Service

U. S. Department of Commerce

Springfield, Virginia 22151

Price: Printed Copy $\$ 3.00$ : Microfiche $\$ 0.65$ 
- RFP-1489

\section{UC-46 CRITICALITY}

STUDIES

TID-4500 - 56th Ed.

\title{
MIXTURES OF PLUTONIUM AND ENRICHED URANIUM IN SLAB GEOMETRY
}

\author{
C. Lee Schuske
}

Donald C. Coonfield

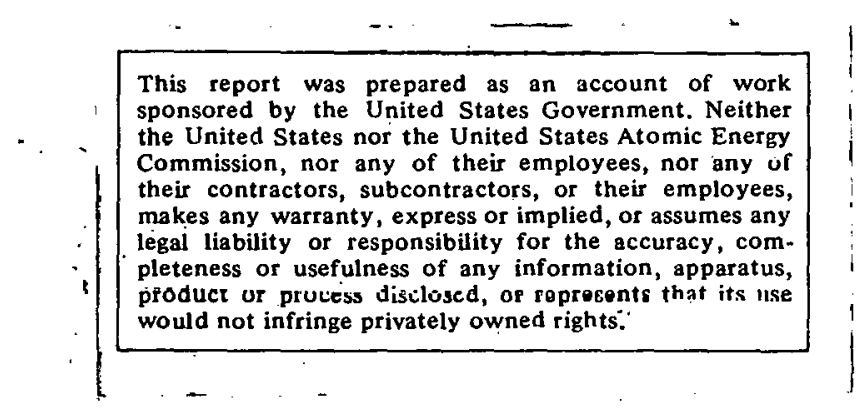

\section{THE DOW CHEMICAL COMPANY} ROCKY FLATS DIVISION

P. O. BOX 888

GOLDEN, COLORADO 80401

Prepared under Controct AT(29-1)-1106

, for the

Albuquerque Operations Office

U. S. Afomic Energy Commission 
RFP-1489 


\section{CONTENTS}

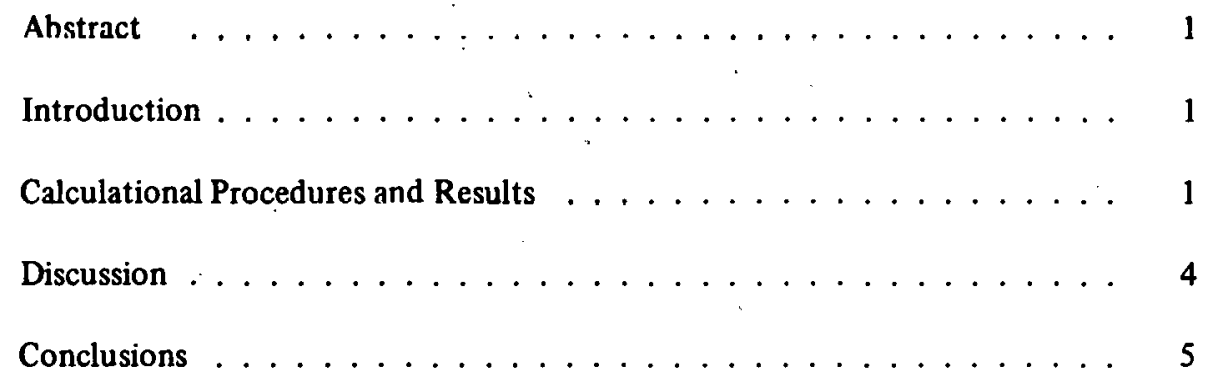




\section{ACKNOWLEDGMENTS}

The helpful suggestions of Deanne Dickinson and Douglas C. Hunt in the preparation of this paper are gratefully acknowledged. L. E. Jackson is acknowledged for preparing the Computer Code DTF input data. 


\title{
MIXTURES OF PLUTONIUM AND ENRICHED URANIUM IN SLAB GEOMETRY
}

\author{
C. Lee Schuske and Donald C. Coonfield
}

\begin{abstract}
The multiplication factors have been calculated for several systems composed of alternate slab regions of plutonium and enriched uranium. The slab systems are unreflected and consist of either pure metal or metal-water solutions at a hydrogen-to-fissile element atomic ratio of 50 . The calculations were done with the Computer Code DTF in the $\mathrm{S}_{4}$ approximation.
\end{abstract}

Slab geometry is used as a simplifying model to simulate possible complex array-storage combinations of plutonium and enriched uranium. The analysis indicates that certain combinations of pure metal are much more reactive than others. For the pure metal case with plutonium surrounded by uranium, the reactivity is 12 percent greater than when the plutonium surrounds the uranium. It is concluded that criticality safety limits for metal storage should include safety margins to account for the effect. For similar hydrogenous systems of plutonium and enriched uranium, only a slight effect was noted.

\section{INTRODUCTION}

In the development of nuclear criticality safety criteria for storage of fissile units, the question arises as to: whether it is permissible to randomly mix units of plutonium $(\mathrm{Pu})$ and uranium (U). F'or example, in a storage array of fissile units, should plutonium and uranium units be alternated or would another arrangement be less reactive.

In this paper, multiplication factor (keff) calculations are perfurmed on unreflected syatems composed of alternate slab regions of plutonium and uranium, in urder lo provide an answcr to the question posed.

The approach avoids the costly Monte Carlo multiplication factor calculations necessary for finite arrays containing discrete fissile units. In addition, the reported approach permits a unique determination of system-composition effects hy eliminating solid-angle effects of array calculations.

\section{CALCULATIONAL PROCEDURES AND RESULTS}

The Computer Code DTF-II ${ }^{1},{ }^{2}$ with the Hansen and Roach ${ }^{3}$ 16-group neutron cross sections is used in all critical parameter calculations. All calculations are done in the $\mathrm{S}_{4}$ approximation using a uniform 75-interval spatial mesh and a $10^{-3}$ convergence criterion. Table I contains the material and nuclear densities used in all calculations.

The first step in the calculational procedure is to obtain the individual critical thicknesses of plutonium and enriched uranium bare slabs. These are 3.68 and 7.16 centimeters $(\mathrm{cm})$, respectively for the metal slabs, and 12.39 and $12.87 \mathrm{~cm}$ for the moderated slabs.

Next, a composite plutonium-uranium slab system is formed by placing a half-critical thickness plutonium slab next to a half-critical thickness uranium slab. Further composite systems are obtained by successively dividing the plutonium and uranium regions and alternating the plutonium and uranium. Figure $l$ is a plot of $k_{e f f}$ as a function of the step homogenization for the bare metal slabs. Figure 2 depicts the systems reviewed. The limit of this process is a homogenous plutonium-uranium mixture. As shown in Figure 2, the total thickness of the plutonium and uranium regions are individually held constant. The calculations indicated that regardless of the degree of homogenization, the multiplication factor for composite systems always remains less than unity.

A second series of calculations was performed to determine if preferential locations of fissile material would lead to a more reactive configuration. Two configurations were chosen. The first consisted of plutonium in the center and uranium on the outside (Configuration I), and the second of uranium in the

\footnotetext{
${ }^{1}$ B. G. Carlson, W. J. Worlton, W. Gruber, and M. Shapiro. DTF Users Manual. UNC Physics - Mathematics 3321. United Nuclear Corporation, White Plains, New York. Volume I, November 1963. Volume II, May 1964.

${ }^{2}$ B. G. Carlson. Methods in Computational Physics, Statistical Physics Volume 1. Editors: Bernte Ader et al Academic Press, New York. 1963. Pages 1-42.

${ }^{3}$ Gordon E. Hansen and William H. Roach. Six and Sixteen Group Cross Sections for Fast and Intermediate Critical A ssemblies. LAMS-2543. University of California, Los Alamos Scientific Laboratory, Los Alamos, New Mexico. 1960.
} 


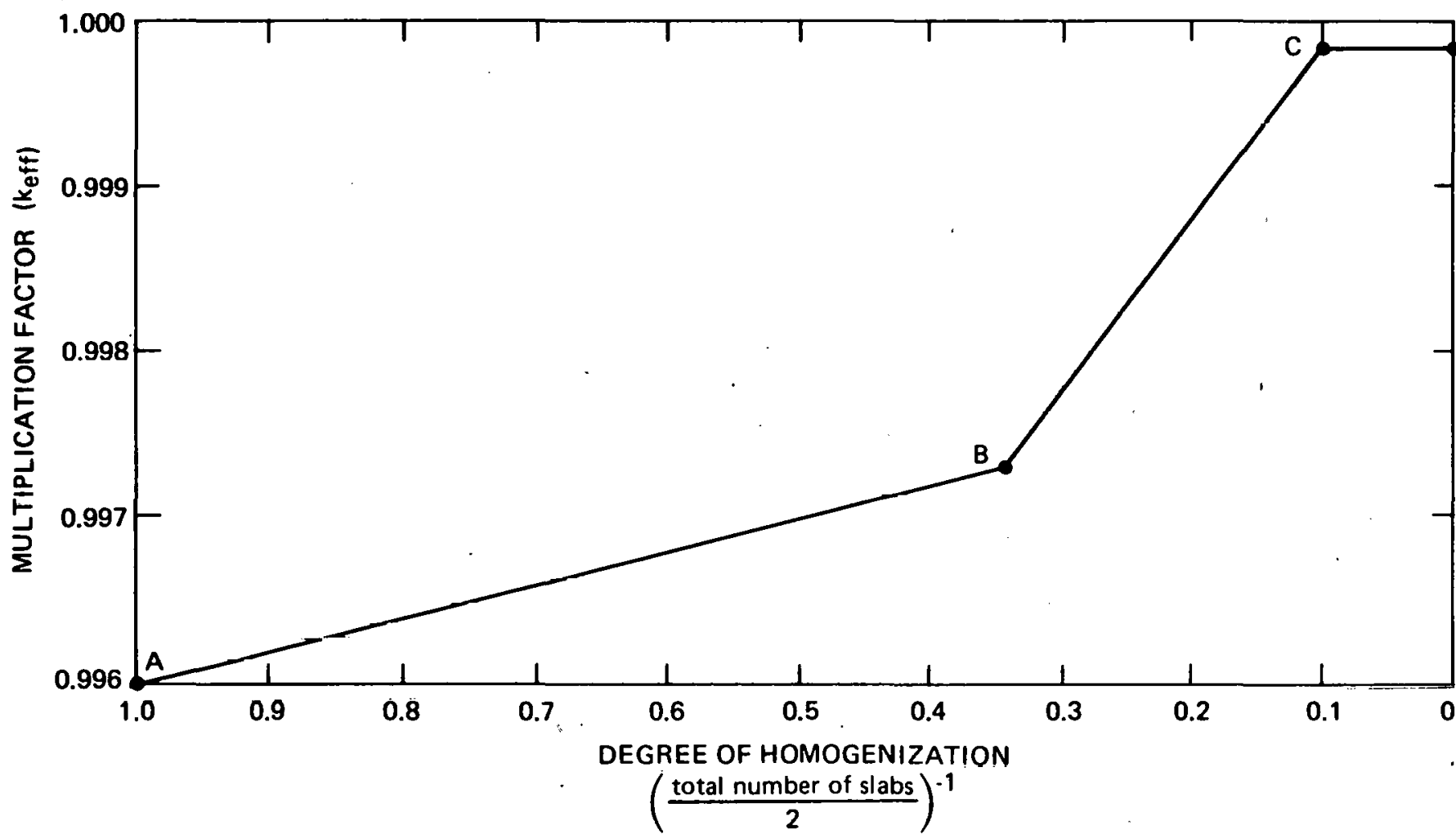

FIGURE 1. Plot of $k_{c f f}$ as a Function of Degree of Homogenization for Bare Metal Slabs. Refer to Systems A, B, and C in Figure 2.

TABLE 1. Densities Used in Computations.

Matarinl

Plutonium Metal

Uranium Metal

$\left(\begin{array}{c}93.0 \text { percent Uranium-235 } \\ \text { and } 7.0 \text { percent Uranium-238 }\end{array}\right)$

Plutonium Metal and

$\left(\frac{\text { Hydrogen }}{\text { Plutonlum }}=50\right)$

Uranium Metal

(93.0 percent Uranium-235 $)$ and

Water Mixture

$\left(\frac{\text { Hydrogen }}{\text { Uranium }}=5 n\right)$ Water Mixture
Nuclear Density

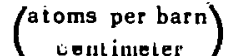

\begin{tabular}{lll}
\hline Plutonium-239 & $=0.04941$ \\
& & \\
Uranium-235 & $=$ & 0.04311 \\
Uranium-238 & $=$ & 0.00324 \\
& & \\
Plutonium-239 & $=0.00129$ \\
Hydrogen & $=$ & 0.06517 \\
Oxygen & $=$ & 0.03258 \\
& & \\
& \\
Uranium-235 & $=0.00120$ \\
Uranium-238 & $=0.00009$ \\
Hydrogen & $=0.06506$ \\
Oxygen & $=0.03253$
\end{tabular}

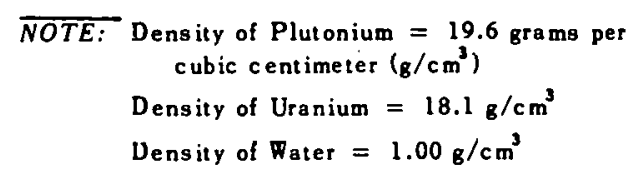

center wilh plutonlum on the oüts̄ide (Configuration Iī). 'l'he configurations are depicted in Figure 3 with the associated results given in Tahle II. Of the two configurations, the one with the plutonium in the center was much more reactive having a $k_{\text {eff }}$ of 1.051 , whilo the second configuration had a $k_{e}$ ff of only 0.948 .

A final series of calculations was performed for bare moderated-metal systems. In the ralculations, the fissile metal is homogenized in water at a hydrogen-tofissile atomic ratio of 50 . The configurations and the calculational results dre shown in Figure 4 and Table II, respectively. The multiplication-factor values change in the same sense as in the previous bare pure metal. rase. The resultant reactivity changes are, however, much smaller.

In Figure 5, Configuraliuns I and II, the total uranium region thickness is maintained at $3.582 \mathrm{~cm}$ (that is the uranium critical half-thickness). Only the plutonium thickness is varied to obtain critical systems. 'These calculations show an approximately 12 percent greater total slab thickness with the plutonium on the outside of the slab than when the plutonium is placed in the center. 


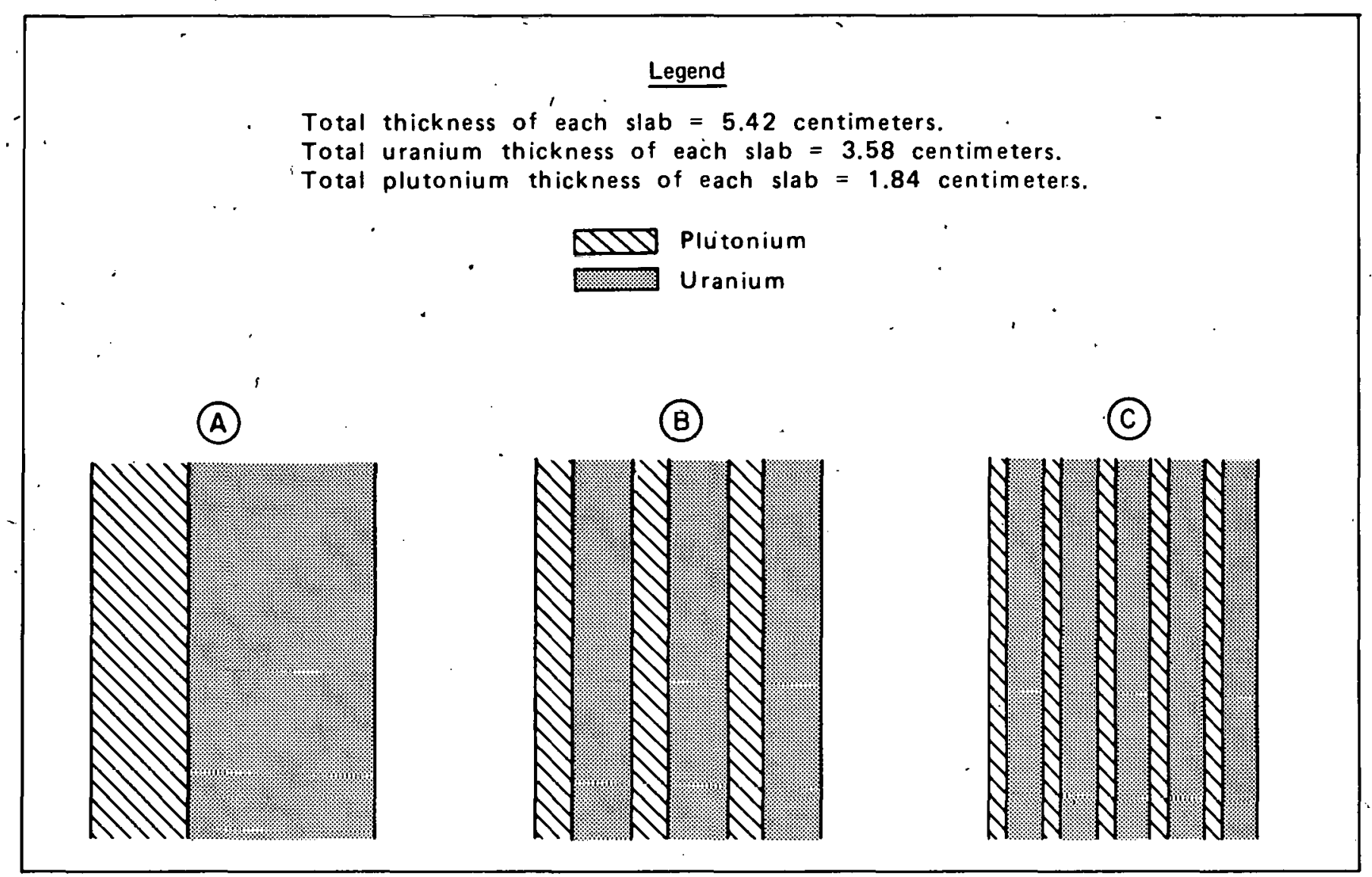

FIGURE 2. Bare Metal Systems A, B, and C.

FIGURE 3: Bare Metal Slab Systems.

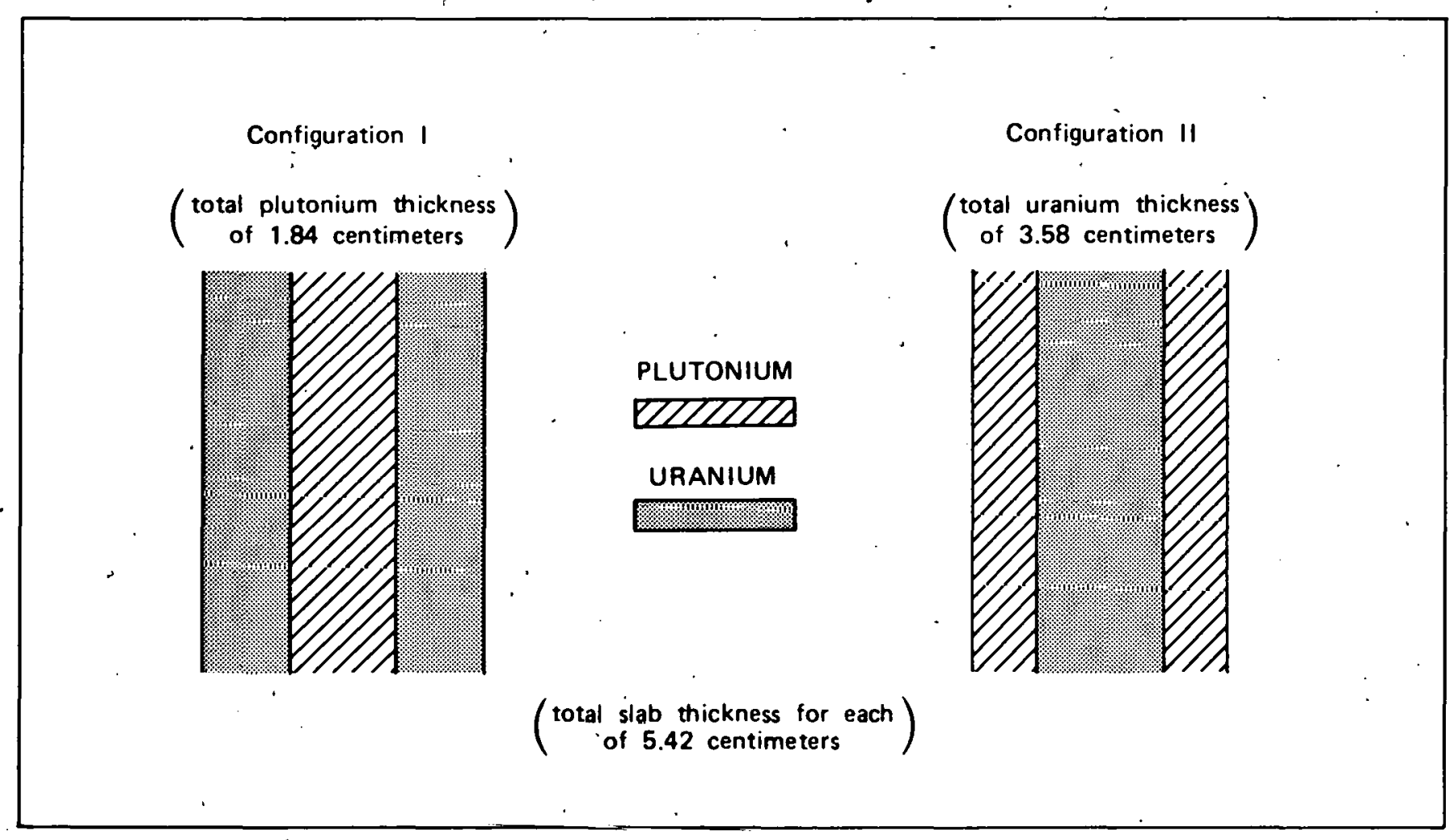




\section{Configuration I}

$\left(\begin{array}{c}\text { total plu tonium thickness } \\ \text { of } 6.19 \text { centimeters }\end{array}\right)$

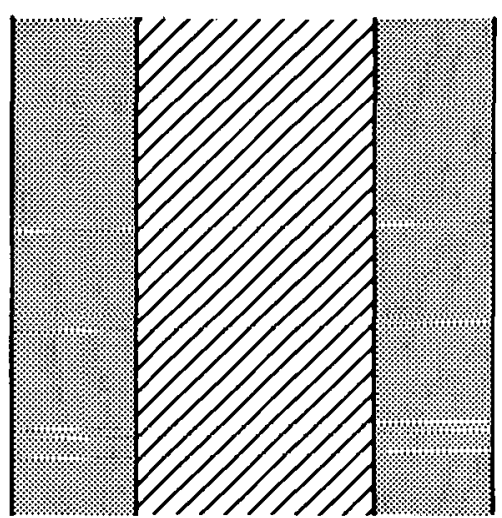

Configuration II
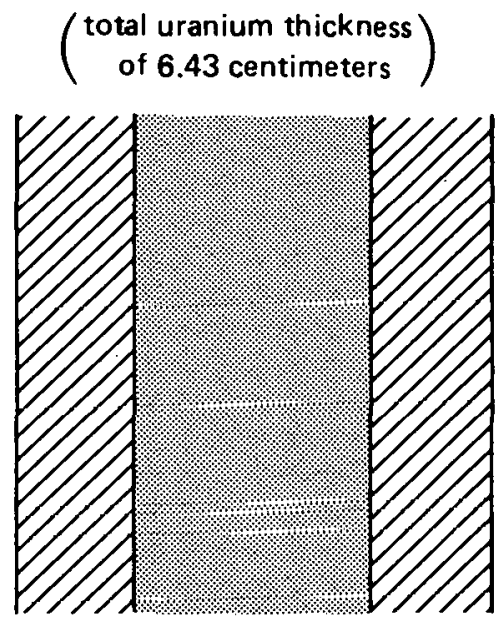

( total slab thickness for each of $)$.

FIGURE 4. Bare Hydrogeneous Slabs at a Hydrogen-to-Fissile Element Atomic Ratio of 50.

\section{DISCUSSION .}

As noted from the results, the most reactive position for the plutonium in a composite plutonium-enriched uranium system is in the center. This can be shown qualitatively as follows.

The reason simply stated is that plutonium has higher values of eta $(\eta)$ (the average number of fission neutrons produced per absorbed incident ne utron), than does uranium. When the plutonium is placed at the center, where the neutron flux is maximum, its effectiveness beromes enhanced.

The following expression can be written to describe the above statement:

$$
k_{\text {eff }}=\frac{\sum_{i j} P_{i j} \eta_{i j} \phi_{i j}}{\sum_{i j \phi_{i j}}}
$$

Where: $k_{\text {eff }}$ is the system multiplication factor

$P_{i j} \quad$ is the system nonabsorption probability for energy group $i$ of neutrons in the spatial interval $j$

$\phi_{\mathrm{ij}}$ is the flux of neutrons in the $\mathrm{ith}$ energy group in the interval $j$

$\eta_{\mathrm{ij}} \quad$ is the average number of fission neutrons produced per àbsorbed incident neutron

In the pure tretal systems, this effect is more pronuunced than in the moderated systems for the following reasons. In the pure metal systems, only the neutrons in the top six energy groups [which range down to 17 kiloelectron volts (keV)] cuntributed significantly to the total reactivity and, in these fast energy groups, the average ratio $\eta \mathrm{Pu} / \eta \mathrm{U}$ is about $\mathrm{l} .23$, while in the lower ten groups, the average ratio $\eta \mathrm{Pu}_{\mathrm{u}} / \eta \mathrm{U}$ is about $l .12$. The last 10 groups contribute significantly to the reactivit) of the moderated case. 


\section{Configuration 1 .}

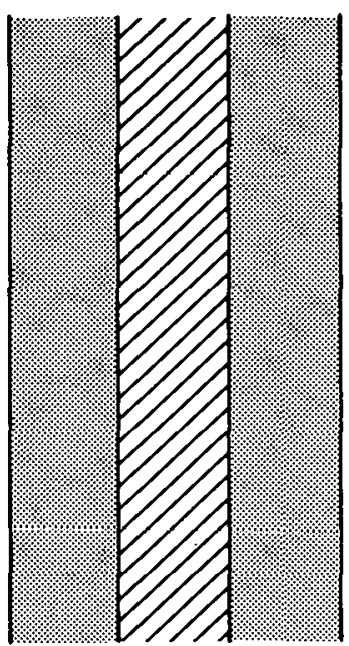

$\begin{gathered}\text { Total plutonium } \\ \text { thickness }\end{gathered}=1.600$ centimeters

$\begin{gathered}\text { Total uranium } \\ \text { thickness }\end{gathered}=3.582$ centimeters

Total slab thickness $=\mathbf{5 . 1 8 2}$ centimeters

\section{Configuration II}

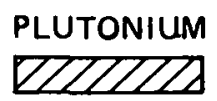

URANIUM
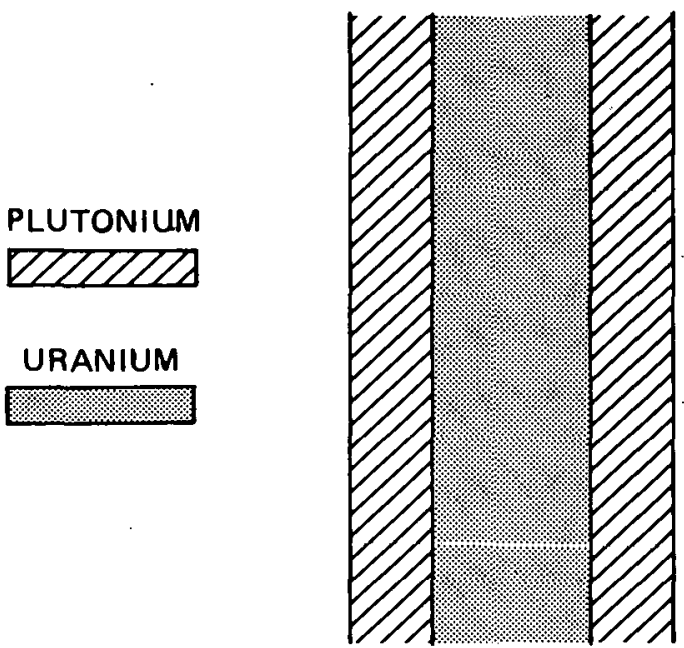

Total plutonium thickness $=2.118$ centimeters

Total uranium thickness

$=3.582$ centimeters

Total slab thickness

$=\mathbf{5 . 7 0 0}$ centimeters

FIGURE 5. Critical $\left(k_{\text {eff }}=1\right)$ Bare Metal Slab Thickness as a Function of Fissile Locations.

TABLE II. The $k_{e f f}$ as a Function of Fissile Location (see Figures 3 and 4 for fissile arrangements).

\begin{tabular}{|c|c|c|c|}
\hline Type of System & $\begin{array}{c}\text { Configuration I } \\
\left(k_{\text {eff }}\right)\end{array}$ & $\begin{array}{c}\text { Configuration II } \\
\left(k_{e f f}\right)\end{array}$ & Figure Nu. \\
\hline$-\quad \cdot$ & & & \\
\hline $\begin{array}{l}\text { Bare Metal Plutonium } \\
\text { and Uranium Slabs }\end{array}$ & 1.054 & 0.948 & 3 \\
\hline $\begin{array}{l}\text { Bapo Modorated Plu- } \\
\text { tonium and Uranium } \\
\text { Slabs }\end{array}$ & 1.002 & 0.996 & 4. \\
\hline
\end{tabular}

\section{CONCLUSIONS}

As noted, any degree of homogenization of plutonium and enriched uranium slabs results in a multiplication factor less than that for corresponding systems of uranium or plutonium alone.

When plutonium is placed in the center of a composite slab system and the uranium is placed on the outside, the mixture results in the most reactive configuration. In the pure metal case, the effect is significant, but for the moderated case only a small effect occurs. The effect noted for bare metal should be considered in the development of criticality rules for mixed storage of plutonium and enriched uranium metal. 